Article

\title{
Impact of Social Support and Social Trust on Public Viral Risk Response: A COVID-19 Survey Study
}

\author{
Eugene Song(1) and Hyun Jung Yoo * \\ Department of Consumer Science, Chungbuk National University, Cheongju 28644, Korea; \\ eugenesong@chungbuk.ac.kr \\ * Correspondence: yoohj@chungbuk.ac.kr
}

Received: 6 August 2020; Accepted: 9 September 2020; Published: 10 September 2020

\begin{abstract}
Public health has been under continuous threat worldwide in recent years. This study examined the impact of social support and social trust on the activities and efficacy of the public's risk response in the case of COVID-19. We conducted an online survey over eight days with 620 Korean adult participants. Data were analyzed using structural equation modelling and K-means cluster analysis. Our results showed that public support had a positive impact on response efficacy, while response efficacy had a positive impact on sanitation, distancing, and purchasing activities. In addition, social support positively moderated the impact of public and individual support on response efficacy, while response efficacy negatively moderated the impact on sanitation activities. These results suggest that, first, amid viral risk, governments should proactively supply tools and information for infection-prevention, and deliver messages that encourage and support infection-prevention activities among the public. Second, when viral risk occurs, governments, along with all other members of society, must engage in aggressive risk response measures. Third, there is a need for risk communication that further emphasizes the importance of personal sanitation activities in the face of viral risk.
\end{abstract}

Keywords: distancing activity; public health; purchasing activity; response efficacy; sanitation activity; social support; social trust; viral risk

\section{Introduction}

In recent years, public health has been under continuous threat worldwide. Among other health threats, the severe acute respiratory syndrome (SARS) epidemic in 2003, the novel influenza virus in 2009, and the Middle East respiratory syndrome (MERS) in 2015 have taken a substantial toll on various societies and their economies [1]. The outbreak of coronavirus disease (COVID-19) in 2020 is viewed as a particularly serious risk, with an enormous global impact, including the closure of national borders and mandatory quarantines. COVID-19 is a respiratory infection that quickly spread around the world since its first outbreak in Wuhan, China. While initially known only as a respiratory infection of unknown etiology, on 9 January 2020, the World Health Organization (WHO) confirmed that the pneumonia was caused by a novel coronavirus [2].

Between 20 January, when the first case of COVID-19 had been confirmed in South Korea, and 16 February 2020, the daily average number of new cases remained at 1.03 . However, the number of confirmed cases began to skyrocket after the diagnosis of the 31st patient on 17 February 2020. According to the South Korean central government and the Korea Centers for Disease Control and Prevention (KCDC) report [2], an average of 207.4 additional confirmed cases per day were reported from 17 February 2020, to 13 April 2020. On 29 February 2020, an additional 1128 cases were confirmed to be infected with COVID-19. Due to aggressive management and prevention measures implemented by the KCDC, the rate of additional diagnoses dropped significantly after 14 April 2020, to an average 
of less than 30 cases per day. However, in June 2020, South Korean authorities announced the potential need for stricter physical measures should the increasing infection rate not subside [3,4].

As COVID-19 is a novel pathogen and, as of August 2020, a vaccine is yet to be developed, South Korean authorities have devoted tremendous efforts to preventing the countrywide spread of COVID-19 by implementing preventive measures such as social distancing, effective handwashing, and coughing etiquette, as well as the careful management of confirmed patients and their close contacts [2]. These measures include the provision of necessary equipment, such as the provision of "public masks," masks provided by designated pharmacies for a low price in response to the soaring prices of facial masks, and the order of a supply of hand sanitizers by major hospitality facilities; the dissemination of information aimed at overcoming the COVID-19 pandemic, such as information on the current number of confirmed cases and patients' paths, correct use of masks and handwashing, and social distancing; and the provision of psychological support through advertisement campaigns that support and encourage people's infection-prevention behaviors [5].

According to Bei et al. [6], a lack of social support at a time of risk has an adverse impact on people's physical and mental health. Horowitz [7] stated that social support is a protective factor moderating psychological impairment in people who had been exposed to a trauma. One factor that is strongly related to risk control is efficacy [8], and social support plays a crucial role in overcoming the COVID-19 pandemic by influencing efficacy [9]. Another important factor is social trust. Social trust is based on cultural values and refers to decisions about whether to trust or distrust anonymous others (people and institutions) [10]. It provides psychological stability when individuals interact with others and is therefore of great import in increasingly atomistic modern societies [11]. Social trust impacts a person's overall perception of risk and their psychological response and behavior related to the risk $[12,13]$, as well as effectively promoting risk recovery [14,15].

Viral risk calls for multilateral infection-prevention efforts by the general public residing in the affected and adjacent regions, even if they have not been infected by the virus, and it is necessary to explore the roles of social support and social trust as potential factors of risk response efficacy among members of the public exposed to a viral risk. Our study aimed to (1) develop and test a model to examine the impact of social support on risk response efficacy and activities during the COVID-19 pandemic; and (2) determine how social trust moderates the impact of social support on risk response efficacy and risk response activities.

This study aimed to show how governments must effectively and proactively provide material, information, and psychological support and that social trust must be fostered through active response activities against the virus by all members of society in order to improve the public's risk response ability and activities. Theoretically, the study findings will be conducive to understanding the public's behavior in the face of viral risk, and practically, the findings will serve as evidence for developing measures to overcome such risk.

\section{Theoretical Background and Hypothesis Development}

\subsection{Social Support and Response Efficacy}

After a disaster, victims mutually interact with various dimensions of the surrounding environment, and social support is one of the most crucial predictors of these interactions [16]. Social support refers to all positive resources people can obtain through interpersonal relationships and the act of interacting with and receiving help from other people to satisfy one's social needs [17]. Song [18] described social support as a positive resource acquired while interacting with others, and stated that it motivates people to engage in a particular action by increasing their will to perform that particular behavior.

Scholars have most commonly categorized social support using two classification types: classification by function of support, namely material support, informational support, and emotional support [18-20]; and classification by the provider of support, namely individual support provided by personal contacts, including family and friends, and public support provided by government and local 
communities [18,21,22]. In this study, we classified social support by provider type (individual and public support) and examined its relationship with response efficacy.

Self-efficacy is an important concept related to perceived control over risk. The construct was first introduced in Bandura's [8] social learning theory and refers to one's belief in one's ability and knowledge for performing a particular behavior [23]. Response efficacy is one of the parameters theoretically related to self-efficacy and is theoretically based on the expectancy value theory [24]. People with a high response efficacy have higher positive expectations for outcomes, increasing their likelihood to engage in a particular behavior. Response efficacy encompasses the construct of self-efficacy, which is one's belief in one's abilities to perform a particular behavior.

The relationship between social support and response efficacy has been the subject of a number of studies. In general, social support has been studied as a factor that increases health behaviors in patients or older adults. Duncan and McAuley [25] and Resnick et al. [26] reported that social support, including public and individual support, indirectly boosts exercise behaviors through efficacy in older adults. Berkman [27] found that peer and colleague support increases individuals' willingness to exercise, thereby demonstrating that individual support has a positive effect on efficacy. Wind et al. [28] found that high levels of cognitive social support leads to better mental health outcomes following a disaster. Further, Bashirian et al. [29] reported that social support affects breast self-examination behavior, implying that social support can boost self-efficacy. Social support also has an important impact on risk. Yoo and Joo [30] and Kim et al. [31] revealed that public information support regarding a risk impacts response efficacy: individuals with more knowledge about a risk showed increased willingness to respond to that risk. Further, Lee and Choi [32] reported that people with a high risk response efficacy are generally more interested in their health and are actually well informed of the ways to protect themselves from harm, while people with a low response efficacy lack knowledge on and belief in the recommended methods for addressing a risk. This indicates that knowing how to control a risk, that is, having informational support, increases response efficacy.

In summary, social support can be classified as public support and individual support and could have a positive impact on response efficacy. Thus, we established the following hypotheses:

Hypothesis 1 (H1). Public support has a positive impact on response efficacy.

Hypothesis 2 (H2). Individual support has a positive impact on response efficacy.

\subsection{Response Efficacy and Activities}

Activities are the outcomes of an individual's final decision based on their pool of information on a risk [33]. If disaster is viewed as a risk, activities can be examined based on people's risk responses. Neal and Griffin [34] defined safety behaviors as behaviors performed to protect one's own safety, help others at risk, or create a safe environment. Song [35] described safety behaviors as self-protective behaviors to prevent a harmful event and as the outcome of individuals' thoughts of ensuring the safety of others and themselves. Safety behaviors during the COVID-19 pandemic are those behaviors demonstrated by the members of the public aimed at protecting themselves and others from the risk of COVID-19.

Korea's Central Disaster Management Headquarters, Central Disease Control Headquarters [2], recommends practicing good personal hygiene, such as properly wearing a facial mask, washing hands frequently, and covering the mouth and nose when coughing or sneezing, to prevent the spread of COVID-19. Further, to prevent direct contact, the Korean public has been advised to refrain from outside activities as much as possible and to practice physical distancing by maintaining a distance of at least $2 \mathrm{~m}$ from each other if they must engage in outside activities. According to Galea et al. [36], the practice of social distancing may be crucial to suppressing the spread of the disease. Preventing COVID-19 infection essentially requires the use of products to help prevent infection, such as face 
masks, antimicrobial and disinfecting products, and antibacterial soap, encouraging the widespread purchase and consumption of these products [37]. Lee and Yoo [38] classified public response activities into precautionary behaviors, including wearing facial masks and hand hygiene, and distancing behaviors, such as a reduced use of public transportation, avoiding crowded places, and postponing or canceling social events. In sum, public responses to the COVID-19 pandemic can be divided into personal hygiene practices, social distancing practices, and purchase of infection-prevention products.

The relationship between efficacy and infection response behaviors has been examined in a number of recent studies. Lee and Yoo [38] reported that self-efficacy positively affected precautionary and distancing activities early in the pandemic. Cui et al. [39] showed that self-response efficacy had an effect on protective intension in the case of avian influenza A/H7N9. Tuma et al. [40] reported that efficacy related to an infectious disease had a positive impact on parents' intention to vaccinate their children. In a study investigating the effects of a media campaigns on influenza-prevention behaviors, Lee et al. [41] observed that people's efficacy related to influenza increased their willingness to comply with prevention recommendations. Chang and Shim [42] also shed light on the fact that efficacy related to infectious diseases such as foot and mouth disease and novel influenza had a positive impact on infection-prevention behavioral intention.

Taken together, response efficacy has a positive impact on infection-prevention behaviors, and we established the following hypotheses:

Hypothesis 3 (H3). Response efficacy has a positive impact on sanitation activity in response to a viral risk.

Hypothesis 4 (H4). Response efficacy has a positive impact on distancing activity in response to a viral risk.

Hypothesis 5 (H5). Response efficacy has a positive impact on purchasing activity in response to a viral risk.

\subsection{Social Trust}

Social trust is derived from trust, a component of social capital [43]. Levi and Stoker [44] stated that social trust is an essential component of social collaboration, and Poortinga and Pidgeon [45] and Mehta et al. [46] also considered trust to be an essential component in interaction pertaining to risk. Social trust can be viewed as an important predictor for overcoming the viral risk of COVID-19, which calls for the cooperation of all members of the society to prevent the spread of infection.

Considering that social trust helps overcome barriers to collective action and effectively promotes resilience and recovery [14], it is also a factor that predicts risk response efficacy and activities. Lui and Mehta [47] reported that trust affects public practice. Rickard et al. [48] also mentioned that interagency trust can enable authorities to coordinate their activities and share information quickly. In particular, social trust helps overcome problems related to collective action that may hinder recovery, and communities with high social trust demonstrate a higher resilience than those with poor social trust [49], suggesting that social trust moderates resilience. The belief that society can complement individuals' vulnerability to risk has a positive effect on risk response efficacy and actions to overcome risk in victims [16,50-52]. Further, Aldrich [49] reported that governments' resilience is based on social trust and bonding. Based on these findings, we hypothesized that social trust would moderate social support, risk response efficacy, and actions to overcome risk, and established the following hypotheses:

Hypothesis 6 (H6). Social trust will moderate the impact of public support on response efficacy.

Hypothesis 7 (H7). Social trust will moderate the impact of individual support on response efficacy.

Hypothesis 8 (H8). Social trust will moderate the impact of response efficacy on sanitation activity.

Hypothesis 9 (H9). Social trust will moderate the impact of response efficacy on distancing activity. 
Hypothesis 10 (H10). Social trust will moderate the impact of response efficacy on purchasing activity.

Freitag and Traunmuller [53] and Uslaner [54] classified trust as specialized and generalized trust. Specialized trust refers to individuals' trust in people they know personally, such as family, friends, and colleagues, while generalized trust refers to a general and rather abstract level of trust among the general public, including strangers, unspecified groups, and broader society [55]. Habibov and Afandi [56] categorized trust into interpersonal trust and institutional trust, and Park [57] examined private trust, including personal connections, and public trust in public institutions. In sum, social trust can be divided into trust in public organizations, such as the government, trust in the general public, and trust in personal contacts.

\section{Methods}

\subsection{Data Collection}

Study data were collected using a questionnaire administered by a professional online survey company, Macomill Embrain, for eight days (18-25 May 2020). The company has a panel of $1,249,392$ adults aged 20 or older, which is equivalent to $3.5 \%$ of the South Korean population. The questionnaire was converted to an online-based survey to make online administration easier and was distributed to a total of 7320 panelists via email. One panelist received no more than two response invitations. Prior to beginning the survey, participants were asked whether they voluntarily provided their consent to participate, and only those who indicated their voluntary consent were allowed to participate in the survey. The panelists that completed the online survey received incentives equivalent to about $\$ 3$. The final response rate was $8.5 \%$. Questionnaire responses collected within a certain time frame were collected and analyzed. A total of 620 participants were selected using the proportionate quota sampling method, which was based on population, gender, age, and area of residence (Table 1). This study received ethics approval from the Research Ethics Committee of Chungbuk National University (CBNU 202006-0109).

Table 1. Descriptive statistics of survey participants $(n=620)$.

\begin{tabular}{ccc}
\hline Characteristics & No & $\%$ \\
\hline Gender & 321 & 51.8 \\
Male & 299 & 48.2 \\
Female & M $=44.67$ & $\mathrm{SD}=13.34$ \\
\hline Age group & 112 & 18.1 \\
20-29 & 109 & 17.6 \\
$30-39$ & 133 & 21.5 \\
$40-49$ & 146 & 23.5 \\
$50-59$ & 120 & 19.4 \\
$\geq 60$ & & \\
Education level & 124 & 20.0 \\
High school or lower & 100 & 16.1 \\
Vocational school & 343 & 55.3 \\
Bachelor's degree & 53 & 8.5 \\
\hline Master's degree and above & M $=477.96$ & SD $=317.36$ \\
\hline Monthly household income * & 51 & 8.2 \\
Under 200 & 201 & 32.4 \\
200-399 & 182 & 29.4 \\
400-599 & 102 & 16.5 \\
600-799 & 84 & 13.5 \\
$\geq 800$ & &
\end{tabular}


Table 1. Cont.

\begin{tabular}{ccc}
\hline Characteristics & No & $\%$ \\
\hline Area of residence & & \\
Metropolitan area & 297 & 47.9 \\
Gyeongsang region & 155 & 25.0 \\
Jeolla-Jeju region & 80 & 12.9 \\
Gangwon-Chungchung region & 88 & 14.2 \\
\hline Occupation & & \\
Full-time employee & 306 & 49.4 \\
Part-time employee & 34 & 5.5 \\
Self-employed & 72 & 11.6 \\
Housewife & 86 & 13.9 \\
Student & 44 & 7.1 \\
Unemployed or other & 78 & 12.6 \\
\hline Notes: * 10,000 South Korean won (USD1 = KRW 1185.00).
\end{tabular}

\subsection{Measures}

In this study, the following six items were developed: public support (PS), individual support (IS), response efficacy $(\mathrm{RE})$, sanitation activity (SA), distancing activity (DA), infection-prevention product purchasing activity (PA), and social trust (ST) (Table 2).

Table 2. Constructs and Survey Questionnaire.

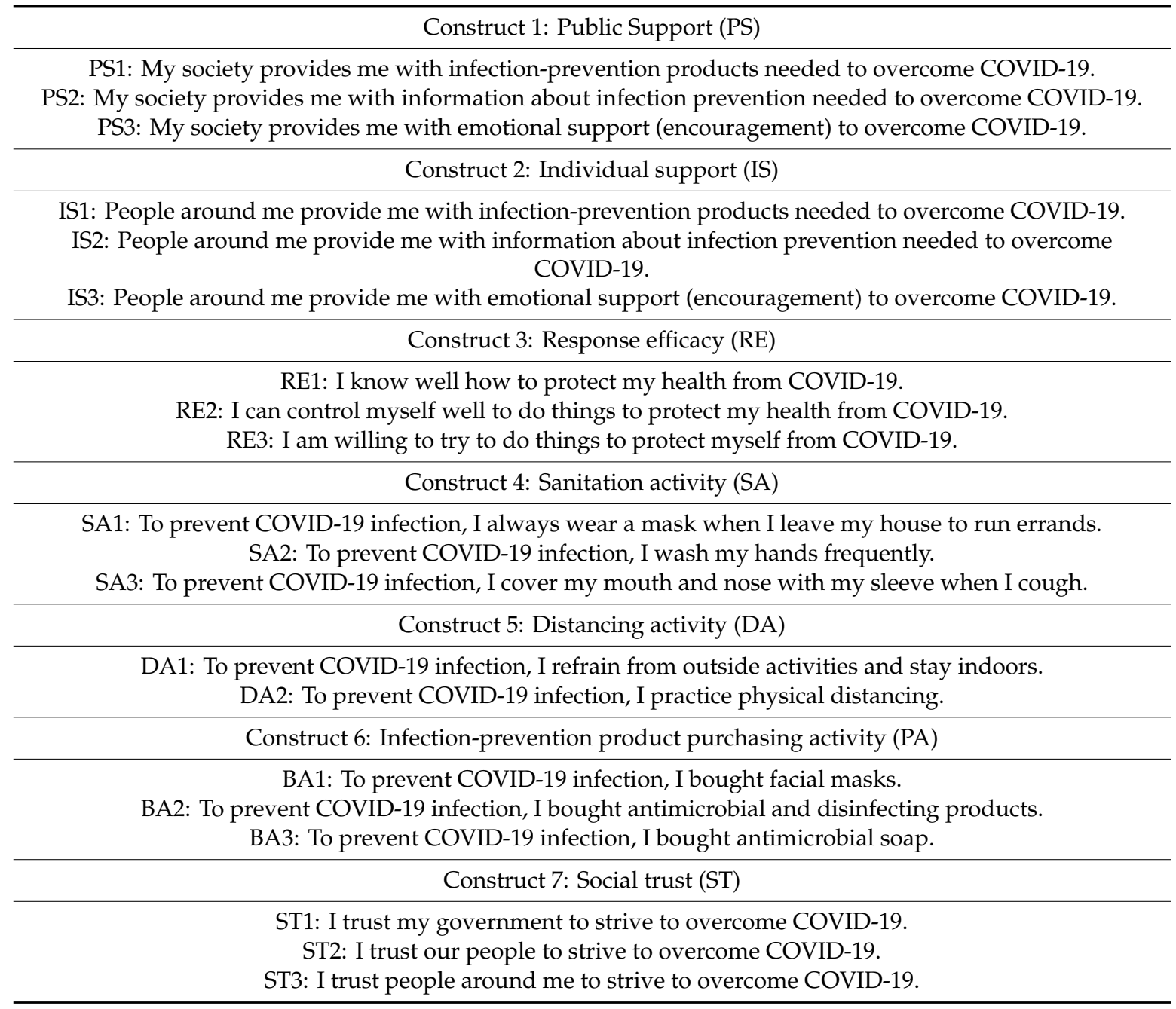




\subsubsection{Social Support}

In this study, we classified social support into public support and individual support based on the source of support, with reference to Song [18] and Rho and Mo [21], and developed hypotheses accordingly. Further, social support was classified into emotional support, informational support, and material support based on the function of support, with reference to Thompson et al. [19], Park [20], and Song [18]. All items were measured on a five-point Likert scale, with $1=$ "strongly disagree," and $5=$ "strongly agree."

\subsubsection{Risk Response Efficacy}

Response efficacy was measured using a modified version of the items for measuring response efficacy developed by Floyd et al. [58] They defined response efficacy as an individual's belief in their ability to engage in activities to protect their own health in the face of risk using the items listed in Table 2. All the items were measured on a five-point Likert scale $(1=$ "strongly disagree"; $5=$ "strongly agree").

\subsubsection{Risk Response Activities}

As previously discussed, COVID-19 response activities can be divided into infection-prevention activities and infection-prevention product purchasing activities, with infection-prevention activities further divided into sanitary activities and distancing activities [2,36-38]. We developed a scale to measure sanitation activity using three items (Table 2) measured on a five-point Likert scale ( $1=$ "strongly disagree"; $5=$ "strongly agree").

\subsubsection{Social Trust}

With reference to Freitag and Traunmuller [53], Uslaner [54], Seo [55], Habibov and Afandi [56], and Park [57], we classified social trust based on public trust (trust in the government), unspecified public trust (trust in the general public), and individual trust (trust in personal acquaintances) and measured perceived trust using the items listed in Table 2 . All the items were measured on a five-point Likert scale ( $1=$ "strongly disagree"; $5=$ "strongly agree").

\subsection{Analysis}

Analyses were done by transferring the data to SPSS 21.0 and AMOS 21.0 software. Participants' demographic characteristics were analyzed using frequency analysis. The baseline measures of each parameter were analyzed with descriptive statistics, namely mean and standard deviation. The validity of the scale was tested with confirmatory factor analysis (CFA) and reliability analysis. This study determines the fitness of the model through the following criteria: the Chi-square minimum/degree of freedom (CMIN/df), the root mean-squared residual (RMR), the root-mean-squared error of approximation (RMSEA), the goodness-of-fit index (GFI), the adjusted-goodness-of-fit index (AGFI), and the comparative-fit index (CFI). For a model with acceptable quality, the following threshold values are recommended: CMIN/df $\leq 5, \mathrm{RMR} \leq 0.05$, RMSEA $\leq 0.08, \mathrm{GFI} \leq 0.9$, AGFI $\geq 0.9, \mathrm{CFI} \leq 0.9$ [59-62]. Further, the reliability of the scale was tested by comparing the standardized and variance estimates computed from CFA, composite reliability (CR), average variance extracted (AVE), square roots of AVEs, and Cronbach's $\alpha$. For a model with acceptable quality, the following threshold values are recommended: $\mathrm{CR} \geq 0.7, \mathrm{AVE} \geq 0.5$, Cronbach's $\alpha \geq 0.7$, square roots of AVEs $\geq$ of the interconstruct correlation coefficient $[63,64]$.

$\mathrm{H} 1-\mathrm{H} 5$ were tested using structural equation modeling (SEM). H6-H10 were tested with reference to the method of testing moderating effects suggested by Harish Sujan and Weitz [64], Woo [65], and Lee and Lim [66]. First, K-means cluster analysis was performed to cluster groups according to the mean values of the moderators. Next, multiple group SEM was performed by applying constraints for each path and the difference in the standardized path coefficients between two corresponding groups 
in the unconstrained model. The path coefficients were considered statistically different when the absolute value of the composite reliability between standardized path coefficients of each group was 1.965 or higher, and a moderating effect was confirmed upon fulfilling this criterion.

\subsection{Model}

We established the following hypotheses and study model to examine the impact of social support on risk response efficacy and activities during the COVID-19 pandemic. Ten study hypotheses were developed to examine the relationships among PS, IS, RE, SA, DA, PA, and ST, and the structure is illustrated in Figure 1.

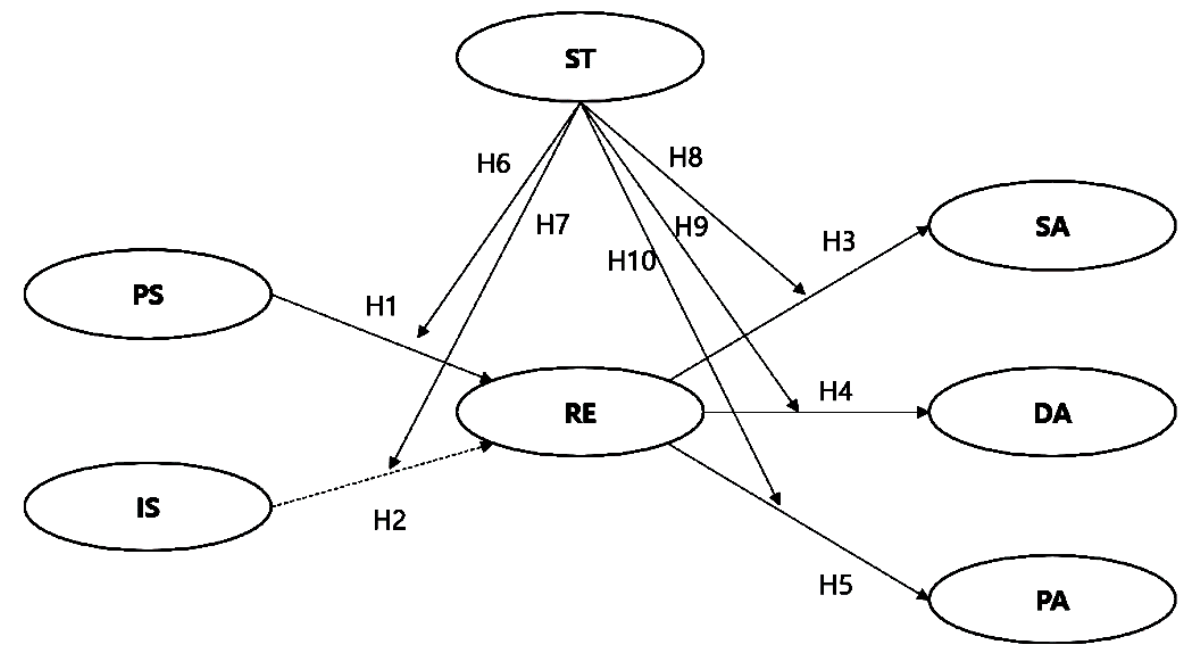

Figure 1. The hypothesized conceptual model. Note: DA, distancing activity; IS, individual support; PA, purchasing activity; PS, public support; RE, response efficacy; SA, sanitary activity; and ST, social trust.

\section{Results}

\subsection{Measurement Model}

To determine whether the measurement model was suitable, we assessed its content validity, convergent validity, and discriminant validity. First, content validity was tested by developing constructs and measurement items based on the literature and conducting a pilot test. Second, convergent validity was tested by examining the fit indices computed in the CFA. The results were $\chi^{2} / \mathrm{df}=2.627, \mathrm{RMR}=0.038, \mathrm{RMSEA}=0.051, \mathrm{AGFI}=0.916$, and $\mathrm{CFI}=0.970$, confirming a good model fit. In addition, standardized estimate, Cronbach's $\alpha, C R$, and AVE were examined. As shown in Table 3, factor loading, Cronbach's $\alpha$, and CRs for each construct were all over the acceptable threshold of 0.7, and AVEs for each item were all higher than the acceptable threshold of 0.5 [67]. Therefore, convergent validity is supported. Discriminant validity was tested using interconstruct correlation coefficients. The square roots of AVEs for each underlined construct are higher than the other values [68].

Table 3. Standardized estimate, reliability, and interconstruct correlations.

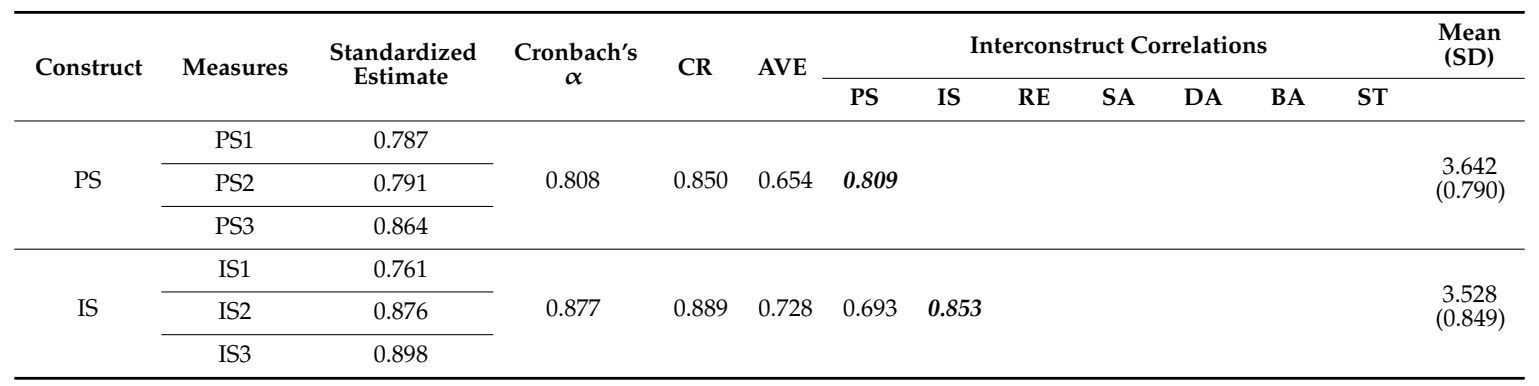


Table 3. Cont

\begin{tabular}{|c|c|c|c|c|c|c|c|c|c|c|c|c|c|}
\hline \multirow{2}{*}{ Construct } & \multirow{2}{*}{ Measures } & \multirow{2}{*}{$\begin{array}{l}\text { Standardized } \\
\text { Estimate }\end{array}$} & \multirow{2}{*}{$\begin{array}{c}\text { Cronbach's } \\
\alpha\end{array}$} & \multirow{2}{*}{ CR } & \multirow{2}{*}{ AVE } & \multicolumn{7}{|c|}{ Interconstruct Correlations } & \multirow{2}{*}{$\begin{array}{l}\text { Mean } \\
\text { (SD) }\end{array}$} \\
\hline & & & & & & PS & IS & RE & SA & DA & BA & ST & \\
\hline \multirow{3}{*}{$\mathrm{RE}$} & RE1 & 0.833 & \multirow{3}{*}{0.906} & \multirow{3}{*}{0.945} & \multirow{3}{*}{0.852} & \multirow{3}{*}{0.346} & \multirow{3}{*}{0.301} & \multirow{3}{*}{0.923} & & & & & \multirow{3}{*}{$\begin{array}{l}4.058 \\
(0.685)\end{array}$} \\
\hline & RE2 & 0.887 & & & & & & & & & & & \\
\hline & RE3 & 0.898 & & & & & & & & & & & \\
\hline \multirow{2}{*}{ SA } & SA1 & 0.855 & \multirow{2}{*}{0.833} & \multirow{2}{*}{0.930} & \multirow{2}{*}{0.827} & \multirow{2}{*}{0.279} & \multirow{2}{*}{0.169} & \multirow{2}{*}{0.639} & \multirow{2}{*}{0.909} & & & & \multirow{2}{*}{$\begin{array}{l}4.215 \\
(0.714)\end{array}$} \\
\hline & SA3 & 0.829 & & & & & & & & & & & \\
\hline \multirow[b]{2}{*}{ DA } & DA1 & 0.905 & \multirow[b]{2}{*}{0.801} & \multirow{2}{*}{0.869} & \multirow[b]{2}{*}{0.770} & \multirow[b]{2}{*}{0.168} & \multirow{2}{*}{0.265} & \multirow{2}{*}{0.205} & \multirow{2}{*}{0.394} & \multirow{2}{*}{0.877} & & & \\
\hline & DA2 & 0.740 & & & & & & & & & & & $\begin{array}{l}4.090 \\
(0.715)\end{array}$ \\
\hline & BA1 & 0.733 & & & & & & & & & & & \\
\hline ST & ST2 & 0.885 & 0.846 & 0.881 & 0.712 & 0.407 & 0.250 & 0.713 & 0.557 & 0.161 & 0.498 & 0.844 & $\begin{array}{c}4.101 \\
(0.761)\end{array}$ \\
\hline & ST3 & 0.786 & & & & & & & & & & & \\
\hline
\end{tabular}

Notes: DA, distancing activity; IS, individual support; PA, purchasing activity; PS, public support; RE, response efficacy; SA, sanitary activity; and ST, social trust.

\subsection{Structural Model 1}

The fit indices were $\chi^{2}=309.592^{* * *}, \mathrm{DF}=107, \mathrm{CMIN} / \mathrm{DF}=2.893, \mathrm{RMR}=0.059, \mathrm{RMSEA}=0.055$, GFI $=0.943$, AGFI $=0.919$, and CFI $=0.969$, based on which the model was determined to have an acceptable fit. Figure 2 illustrates the structural model, where a solid line represents the model supporting the study hypothesis and a dotted line represents the rejection of the study hypothesis. PS had a positive effect on RE $(\beta=0.268, p<0.000)$, supporting H1. However, IS did not have a statistically significant effect on RE, not supporting $\mathrm{H} 2$. Next, RE had a statistically significant effect on SA $(\beta=0.639, p<0.000)$, DA $(\beta=0.649, p<0.000)$, and PA $(\beta=0.212, p<0.000)$, thereby supporting $\mathrm{H} 3, \mathrm{H} 4$, and $\mathrm{H} 5$.

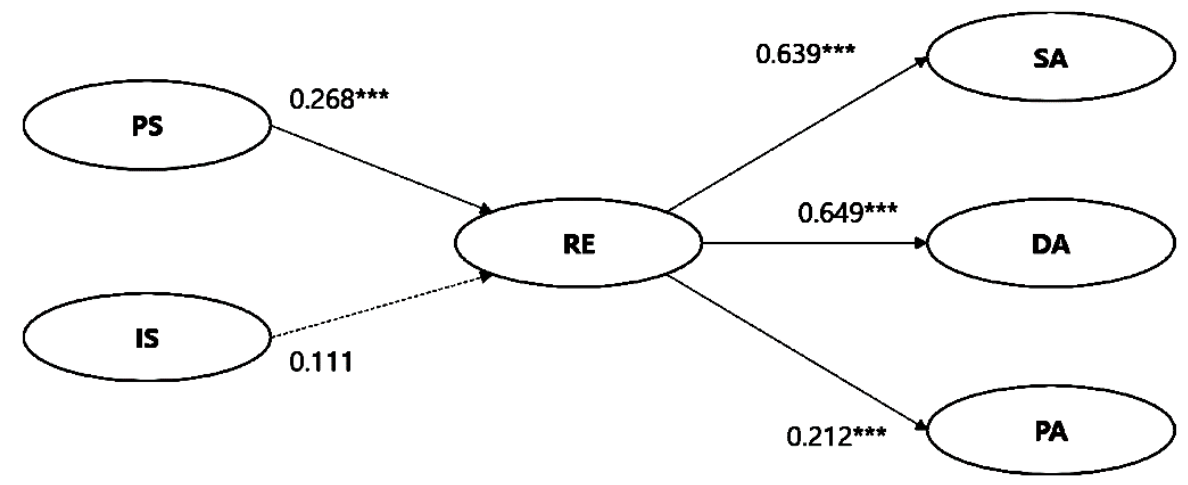

Figure 2. Structural model with standardized path coefficients. Note: ${ }^{* *} p<0.001$. DA, distancing activity; IS, individual support; PA, purchasing activity; PS, public support; RE, response efficacy; SA, sanitary activity; and ST, social trust.

\subsection{Structural Model 2}

K-means cluster analysis was performed to divide the group with high ST from that with low ST. The high ST group consisted of $507(81.8 \%)$ people, with a mean ST score of $4.381( \pm 0.455)$. The low ST group consisted of $113(18.2 \%)$ people and had a mean ST score of $2.844( \pm 0.560)$.

The moderating effect of ST was analyzed with multiple group SEM for each group. The fit indices were $\chi^{2}=438.024^{* * *}, \mathrm{DF}=214, \mathrm{CMIN} / \mathrm{DF}=2.047, \mathrm{RMR}=0.052, \mathrm{RMSEA}=0.041, \mathrm{GFI}=0.935$, AGFI $=0.903$, and CFI $=0.961$, based on which the model was deemed acceptable. Figure 3 shows a 
diagram of the analysis of the moderating effects of ST, where a solid line represents the presence of a moderating effect by ST, that is, supporting the study hypothesis, and a dotted line represents the absence of a moderating effect by ST, that is, rejecting the study hypothesis. CRs that differ according to the standardized path coefficients of the two groups are indicated in italics and underlined.

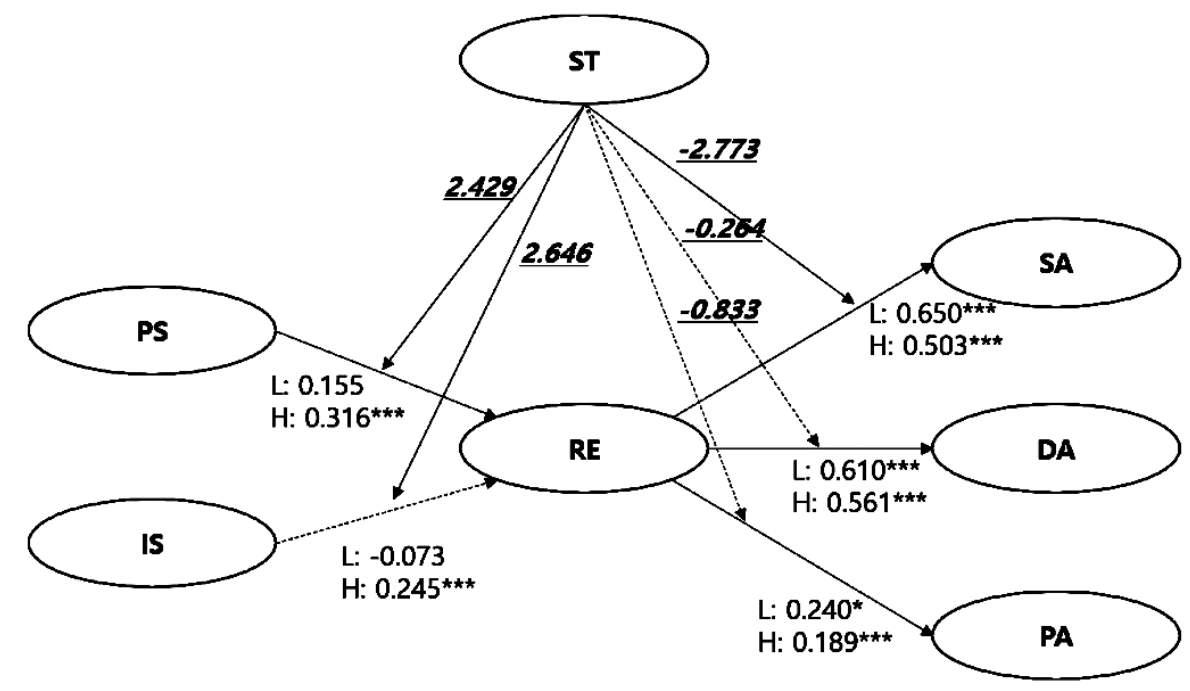

Figure 3. Structural model with standardized path coefficients and composite reliability between low and high groups on social trust. Note: ${ }^{*} p<0.05,{ }^{* *} p<0.001$. DA, distancing activity; IS, individual support; PA, purchasing activity; PS, public support; RE, response efficacy; SA, sanitary activity; and ST, social trust.

First, ST moderated the effect of PS $(C R=2.429)$ and IS $(C R=2.646)$ on RE. While these two paths were statistically significant in the high ST group, they were not significant in the low ST group, thereby supporting H6 and H7. Next, ST moderated the effect of RE on SA (CR $=-2.773)$. In other words, the effect of RE on SA was greater in the low ST group compared to the high ST group, supporting H8. On the other hand, ST did not mediate the effect of RE on DA and PA, and thus, H9 and H10 were rejected.

\section{Discussion}

Our findings hold important implications for public health responses to viral risk. First, governments should aggressively provide products and information related to infection prevention and deliver messages to support and encourage public practice of infection-prevention activities. During times of viral risk, the government's material, informational, and psychological support to the public have a direct impact on the public's risk response efficacy and indirectly impacts their sanitary, distancing, and infection-prevention product purchasing activities. Further, support provided by the government is more effective than that provided by personal contacts such as families and friends. This is supported by Yan et al. [69], who showed that social support decreased depression and increased resilience in relation to the risk of virus infection. Furthermore, Labrague and De los Santos [70] mentioned that social support was associated with decreased levels of anxiety related to the COVID-19 pandemic and enhanced personal resilience.

Second, governments and all members of society must collaboratively respond to risks. The climate facilitated by such viral risk response translates to social trust, and high social trust improves the ability to respond to risk. Kuipers [71] and Roque et al. [72] reported that social trust in government institutions cannot prevent an individual from being affected by COVID-19, but it can help strengthen responses at all levels.

Third, risk communication that further emphasizes the importance of personal hygiene behaviors is needed. The impact of response efficacy on sanitation activities declined when social trust, the belief 
that all members of society will actively respond to the virus, was high compared to when it was low. This suggests that once a safe environment has been fostered through active responses against the virus by all members of society, individuals can become more complacent and lower their sanitation activities. According to the protection motivation theory [73], the public is motivated to engage in activities to protect themselves once they feel vulnerable to a risk. On the other hand, their motivation to engage in risk response activities is lost once they determine that the environment is safe. However, lowering the level of social trust because it diminishes sanitary activities may have an adverse impact on people's ability to respond to a risk. Therefore, to promote sanitary activities in response to a viral risk, it is necessary to motivate the public to protect themselves, for which risk communication stressing the importance of personal hygiene behaviors during a viral risk is crucial. This is supported by our findings that social support provided by the government has both a direct and indirect impact on the public's risk response efficacy and activities.

\section{Limitations}

This study has the following limitations. First, among many factors that impact the public's risk response ability and activities, we only focused on the effects of social support and social trust. Subsequent studies should examine a more diverse set of variables. Second, the study population was confined to the Korean population. As a viral risk is a global health threat, it is important to conduct studies in different countries and cultures and comparatively analyze the results. Third, our use of an online survey generated sampling bias, as online surveys are only available for people who use the Internet.

\section{Conclusions}

This study identified the structure of social support, response efficacy, public activities, and social trust. In conclusion, governments must effectively and proactively provide material, informational, and psychological support, and social trust must be fostered through active response activities against the virus by all members of society in order to improve the public's risk response ability and activities. This study shows that social support and social trust improve the public's risk response ability and activities. Theoretically, the study findings will be conducive for understanding the public's behavior in the face of viral risk. Furthermore, this study indicates that public support is more effective than individual support. Practically, the findings will serve as evidence for developing measures to overcome viral risk. These results might be used to organize the contents of virus infection-prevention campaigns for the public or to seek ways to actively prevent infection through material and psychological support.

Author Contributions: Conceptualization, E.S. (first author) and H.J.Y.; methodology, E.S.; software, E.S.; validation, H.J.Y.; formal analysis, E.S.; investigation, E.S.; resources, E.S.; data curation, E.S.; writing-original draft, E.S.; writing-review and editing, E.S. and H.J.Y.; visualization, E.S.; supervision, H.J.Y. All authors have read and agreed to the published version of the manuscript.

Funding: This work was supported by the Ministry of Education of the Republic of Korea and the National Research Foundation of Korea (NRF-2017S1A5B8059946).

Conflicts of Interest: The authors declare no conflict of interest.

\section{References}

1. Cho, K.Y.; Yoo, J.S. Estimation of financial loss from the MERS epidemic. KERI Insight 2015, 15, 1-16.

2. Central Disaster Management Headquarters; Central Disease Control Headquarters. Knowing the Coronavirus Infection. Available online: http://ncov.mohw.go.kr/ (accessed on 12 May 2020).

3. Jones, S.; Anderson, C. 2020. Global Report: South Korea Has Covid-19 Second Wave as Israel Ponders New Lockdown. The Guardian. 22 June 2020. Available online: https://www.theguardian.com/world/2020/jun/22/ coronavirus-global-report-new-covid-19-cases-surge-south-korea-israel (accessed on 24 June 2020). 
4. Gutierrez, J.; Blinder, A.; Sang-Hun, C.; Onishi, N.; Méheut, C.; Zaveri, M.; Joseph, Y.; Kingsley, P.; Austen, I.; Beech, H.; et al. Coronavirus Spread Speeds up, Even as Nations Reopen. The New York Times. 28 May 2020. Available online: https://www.nytimes.com/2020/05/28/world/coronavirus-live.html?partner =naver (accessed on 24 June 2020).

5. Kwon, S.H. "Let's Overcome the Coronavirus Crisis Together": Nationwide Encouraging Campaign “Challenge Again". Yonhap News. 21 June 2020. Available online: https://www.yna.co.kr/view/AKR20200620 050000530?input $=1195 \mathrm{~m}$ (accessed on 24 June 2020).

6. Bei, B.; Bryant, C.; Gilson, K.; Koh, J.; Gibson, P.; Komiti, A.; Jackson, H.; Judd, F. A prospective study of the impact of floods on the mental and physical health of older adults. Aging Ment. Health 2013, 17, 992-1002. [CrossRef] [PubMed]

7. Horowitz, M. Stress-response syndromes: A review of post-traumatic stress and adjustment disorders. In International Handbook of Traumatic Stress Syndromes; Wilson, J.P., Raphael, Y.B., Eds.; Plenum Press: New York, NY, USA, 1993; pp. 189-200.

8. Bandura, A. Self-Efficacy: The Exercise of Control; Freeman: New York, NY, USA, 1997.

9. Xiao, H.; Zhang, Y.; Kong, D.; Li, S.; Yang, N. The effects of social support on sleep quality of medical staff treating patients with coronavirus disease 2019 (COVID-19) in January and February 2020 in China. Med. Sci. Monit. 2020, 26, e923549. [CrossRef] [PubMed]

10. Earle, T.C.; Cvetkovich, G. Social trust and culture in risk management. In Social Trust and the Management of Risk; Cvetkovich, G., Lofstedt, R., Eds.; Routledge: London, UK, 1999; pp. 9-21.

11. Sønderskov, K.M.; Dinesen, P.T. Trusting the state, trusting each other? The effect of institutional trust on social trust. Polit Behav. 2016, 38, 179-202. [CrossRef]

12. Song, E. A study on risk perception, risk information acceptance, safety attitude, and safety actions of consumers according to the types of exposure to risk communication-based on the application of the consumers' risk information acceptance models. Consum. Policy Educ. Rev. 2019, 15, 49-70. [CrossRef]

13. Yoo, H.J.; Song, E. The effect of information reliability on safety behavior among Korean, Chinese and American university student: Focused on food consumption. Korean Rev. Crisis Emerg. Manag. 2013, 9, 101-120.

14. Adger, N.W.; Hughes, T.P.; Folke, C.; Carpenter, S.R.; Rockstrom, J. Social-ecological resilience to coastal disasters. Science 2005, 309, 1036-1039. [CrossRef]

15. Nakagawa, Y.; Shaw, R. Social capital: A missing link to disaster recovery. Int. J. Mass. Emerg. Disasters 2004, 22, 5-34.

16. Lee, N.B. A Meta-Analysis Study of Predictors of Disaster Victims' Post-Traumatic Stress Response Based on Ecological Model. Ph.D. Thesis, Ewha Women's University Graduate School, Seodaemun-gu, Seoul, Korea, 2016.

17. Kim, K.; Lee, K.H. A study on social support and school-life adjustment of middle school student. Korean J. Fam. Welfare 1997, 2, 145-165.

18. Song, E. The effects of green commitment and social support on consumers' environment-friendly practice actions. Consum. Policy Educ. Rev. 2020, 16, 65-88. [CrossRef]

19. Thompson, E.H.; Futterman, A.M.; Gallagher-Thompson, D.; Rose, J.M.; Lovett, S.B. Social support and caregiving burden in family caregivers of frail elders. J. Gerontol. 1993, 48, 245-254. [CrossRef] [PubMed]

20. Park, J.W. A study on the Development of a Social Support Scale. Ph.D. Thesis, Yonsei University Graduate School, Seoul, Korea, February 1985.

21. Rho, B.; Mo, S.H. The effect of levels and dimensions of social support on geriatric depression. J. Korea Gerontol. Soc. 2007, 27, 53-69.

22. Babcicky, P.; Seebauer, S. The two faces of social capital in private flood mitigation: Opposing effects on risk perception, self-efficacy and coping capacity. J. Risk. Res. 2017, 20, 1017-1037. [CrossRef]

23. Prentice-Dunn, S.; Mcmath, B.F.; Cramer, R.J. Protection motivation theory and stages of change in sun protective behavior. J. Health Psychol. 2009, 14, 297-305. [CrossRef]

24. Fishbein, M.; Ajzen, I. Belief, Attitude, Intention, and Behavior: An Introduction to Theory and Research; Addison-Wesley: Reading, MA, USA, 1975.

25. Duncan, T.E.; McAuley, E. Social support and efficacy cognitions in exercise adherence: A latent growth curve analysis. J. Behav. Med. 1993, 16, 199-218. [CrossRef] 
26. Resnick, B.; Orwig, D.; Magaziner, J.; Wynne, C. The effect of social support on exercise behavior in older adults. Clin. Nurs. Res. 2002, 11, 52-70. [CrossRef]

27. Berkman, L.F. The role of social relations in health promotion. J. Biobehav. Med. 1995, 57, 245-254. [CrossRef]

28. Wind, T.R.; Fordham, M.; Komproe, I.H. Social capital and post-disaster mental health. Glob. Health Action 2011, 4, 6351. [CrossRef]

29. Bashirian, S.; Barati, M.; Shoar, L.M.; Mohammadi, Y.; Dogonchi, M. Factors affecting breast self-examination behavior among female healthcare workers in Iran: The role of social support theory. J. Prev. Med. Public Health 2019, 52, 224-233. [CrossRef]

30. Yoo, H.J.; Joo, S.H. Structural Equation analysis on consumers' perceived food safety and food safety orientation behavior. Consum. Policy Educ. Rev. 2012, 8, 49-70.

31. Kim, K.H.; Yoo, H.J.; Song, E. An analysis on the structural model for consumer trust-anxiety-competency by source of information-focused on chemical household products. Crisisonomy 2017, 13, 141-158. [CrossRef]

32. Lee, J.; Choi, J. Irrationality of risk judgment: Framing the size of risk casualties and its effects on optimistic bias. Korean J. Journal. Commun. Stud. 2014, 58, 40-63.

33. Kwak, C.; Lee, Y.H. Media usages based on the characteristics of disasters, and social capital as an information delivery channel: Focusing on the effects on pre-preparedness behaviors against disasters. J. Commun. Sci. 2014, 14, 5-41. [CrossRef]

34. Neal, A.; Griffin, M.A. Safety climate and safety behaviour. Aust. J. Manag. 2002, 27, 67-76. [CrossRef]

35. Song, E. Development of the Consumers' Risk Information Acceptance Models According to Risk Communication Type. Ph.D. Thesis, Chungbuk National University Graduate School, Cheongju-si, Korea, 2016.

36. Galea, S.; Merchant, R.M.; Lurie, N. The mental health consequences of COVID-19 and physical distancing: The need for prevention and early intervention. JAMA Int. Med. 2020, 180, 817-818. [CrossRef]

37. Smith, G.D.; Ng, F.; Li, W.H.C. COVID-19: Emerging compassion, courage and resilience in the face of misinformation and adversity. J. Clin. Nurs. 2020, 29, 1425. [CrossRef] [PubMed]

38. Lee, M.; Yoo, M. Psychological and behavioral responses in South Korea during the early stages of coronavirus disease 2019 (COVID-19). Int. J. Environ. Public Health 2020, 17, 2977. [CrossRef] [PubMed]

39. Cui, B.; Liao, Q.; Lam, W.W.T.; Liu, Z.P.; Fielding, R. Avian influenza A/H7N9 risk perception, information trust and adoption of protective behaviors among poultry farmers in Jiangsu Province, China. BMC Public Health 2017, 17, 463. [CrossRef]

40. Tuma, J.N.; Smith, S.M.; Kirk, R.H.; Hagmann, C.E.; Zemel, R.C. Beliefs and attitudes of caregivers toward compliance with childhood immunisations in Cameroon. Public Health 2002, 116, 55-61. [CrossRef]

41. Lee, B.K.; Oh, H.J.; Shin, K.A.; Ko, J.Y. The effect of media campaign as a cue to action on influenza prevention behavior: Extending health belief model. Korean J. Advert. Public Relat. 2008, 10, 108-138.

42. Chang, J.; Shim, J. Testing the links between health belief model, optimistic bias, and behavioral intention: The case study of foot-and-mouth disease, mad cow disease, and H1N1 flu. Korean J. Journal. Commun. Stud. 2013, 57, 111-137.

43. Putnam, R.D. Making Democracy Work: Civic Traditions in Modern Italy; Princeton University Press: Princeton, NJ, USA, 1993.

44. Levi, M.; Stoker, L. Political trust and trustworthiness. Annu. Rev. Polit. Sci. 2000, 3, 475-507. [CrossRef]

45. Poortinga, W.; Pidgeon, N.F. Exploring the dimensionality of trust in risk regulation. Risk. Anal. 2003, 23, 961-972. [CrossRef] [PubMed]

46. Mehta, A.; Bruns, A.; Newton, J. Trust, but verify: Social media models for disaster management. Disasters 2017, 41, 549-565. [CrossRef]

47. Lui, B.F.; Mehta, A.M. From the periphery and toward a centralized model for trust in government risk and disaster communication. J. Risk. Res. 2020. [CrossRef]

48. Rickard, L.N.; McComas, K.A.; Clarke, C.E.; Stedman, R.C.; Decker, D.J. Exploring risk attenuation and crisis communication after a plague death in Grand Canyon. J. Risk. Res. 2013, 16, 145-167. [CrossRef]

49. Aldrich, D.P. Building Resilience: Social Capital in Post-Disaster Recovery; University of Chicago Press: Chicago, IL, USA, 2012.

50. Choi, S.M.; Kim, Y.J.; Kwon, J.H. (2013). Effects of cognitive and behavioral coping and social supports on post-traumatic growth: Depending on PTSD symptom severity. Cogn. Behav. Ther. Korea 2013, 13, 307-328. 
51. Jackson, Y.; Warren, J.S. Appraisal, social support, and life events: Predicting outcome behavior in school-age children. Child. Dev. 2000, 71, 1441-1457. [CrossRef]

52. Prati, G.; Pietrantoni, L. Optimism, social support, and coping strategies as factors contributing to posttraumatic growth: A meta-analysis. J. Loss. Trauma. 2009, 14, 364-388. [CrossRef]

53. Freitag, M.; Traunmuller, R. Spheres of trust: An empirical analysis of the foundations of particularised and generalised trust. Eur. J. Polit. Res. 2009, 48, 782-803. [CrossRef]

54. Uslaner, E.M. Trust and the economic crisis of 2008. Corp. Reput. Rev. 2008, 13, 110-123. [CrossRef]

55. Seo, C.R. Mediating effects of economic strain and social trust, and moderating effects of socio-demographic characteristics on the relationships between family economic hardships and couples life satisfaction. Korean J. Hum. Ecol. 2018, 27, 349-367. [CrossRef]

56. Habibov, N.; Afandi, E. Pre- and post-crisis life-satisfaction and social trust in transitional countries: An initial assessment. Soc. Indic. Res. 2015, 121, 503-524. [CrossRef]

57. Park, G.S. Social capital and quality of life. J. Asiat. Stud. 2002, 45, 109-139.

58. Floyd, D.L.; Prentice-Dunn, S.; Rogers, R.W. A meta-analysis of research on protection motivation theory. J. Appl. Soc. Psychol. 2000, 30, 407-429. [CrossRef]

59. Tobbin, P. Adoption of mobile money transfer technology: Structural equation modeling approach. Eur. J. Bus. Manag. 2011, 3, 59-77.

60. Joreskog, K.G.; Sorbom, D. Lisrel 8: Structural Equation Modelling with the SIMPLIS Command Language; Scientific Software International: Chicago, IL, USA, 1996.

61. Byrne, B.M. Structural Equation Modelling with AMOS: Basic Concepts, Applications and Programming; Lawrence Erlbaum Associates: Mahwah, NJ, USA, 2001.

62. Balong, A. Acceptance of e-learning systems: A serial multiple meditation analysis. Stud. Inform. Control 2015, 24, 101-110.

63. Chen, J.; Lan, Y.C.; Chang, Y.W.; Chang, P.Y. 2019. Exploring doctors' willingness to provide online counseling services: The roles of motivations and costs. Int. J. Environ. Res. Public Health. 2019, 17, 110. [CrossRef]

64. Harish Sujan, B.A.; Weitz, N.K. Learning orientation, working smart, and effective selling. J. Mark. 1994, 58, 39-52. [CrossRef]

65. Woo, J.P. Professor Woo Jong-pil's Concept and Understanding of the Structural Equation Model; Han Narae: Seoul, Korea, 2013.

66. Lee, H.S.; Lim, J.H. Structural Equation Modeling with AMOS 6.0; Bobmunsa Publisher: Paju, Korea, 2007.

67. Fornell, C.; Larcker, D.F. Evaluating structural equation models with unobservable variables and measurement error. J. Mark. Res. 1981, 18, 39-50. [CrossRef]

68. Nunnally, J.C. Psychom. Theory; McGraw-Hill: New York, NY, USA, 1978.

69. Yan, H.; Li, X.; Li, J.; Wang, W.; Yang, Y.; Yao, X.; Yang, N.; Li, S. Association between perceived HIV stigma, social support, resilience, self-esteem, and depressive symptoms among HIV-positive men who have sex with men (MSM) in Nanjing, China. Psychol. Sociomed. Aspects AIDS/HIV 2019, 31, 1069-1976. [CrossRef]

70. Labrague, L.J.; De los Santos, J.A.A. COVID-19 anxiety among front-line nurses: Predictive role of organizational support, personal resilience and social support. J. Nurs. Manag. 2020, 1-9. [CrossRef]

71. Kuipers, S. Editorial: Sanity and resilience in times of Corona. Risk. Hazards Crisis Public Policy 2020, 11, 110-115. [CrossRef]

72. Roque, A.D.; Pijawka, D.; Wutich, A. The role of social capital in resiliency: Disaster recovery in Puerto Rico. Risk Hazards Crisis Public Policy 2020, 11, 204-235. [CrossRef]

73. Roger, R.W. A protection motivation theory of fear appeals and attitude change. J. Psychol. 1975, 91, 93-114. [CrossRef]

(C) 2020 by the authors. Licensee MDPI, Basel, Switzerland. This article is an open access article distributed under the terms and conditions of the Creative Commons Attribution (CC BY) license (http://creativecommons.org/licenses/by/4.0/). 